\title{
Production and Characterization of Colored Feldspathic Enamel for Dental Application
}

\author{
Shirleny F. Santos ${ }^{\mathrm{a} *}$, Mônica C. de Andrade ${ }^{\mathrm{b}}$,João A. Sampaio ${ }^{\mathrm{c}}$, \\ Adão B. da Luz, Tsuneharu Ogasawara \\ ${ }^{a}$ Centro Universitário Estadual da Zona Oeste - UEZO, Av. Manuel Caldeira de Alvarenga, \\ CEP 23070-200, Rio de Janeiro, RJ, Brasil \\ ${ }^{\mathrm{b}}$ Departamento de Engenharia Mecânica, Universidade do Estado do Rio de Janeiro - UERJ, \\ Rua Alberto Rangel, s/n, Vila Nova, CEP 28630-050, Nova Friburgo, RJ, Brasil \\ ${ }^{\circ}$ Centro de Tecnologia Mineral - CETEM, Av. Pedro Calmon, 900, Cidade Universitária, \\ CEP 21941-980, Rio de Janeiro, RJ, Brasil \\ dPrograma de Engenharia Metalúrgica e de Materiais - COPPE, \\ Universidade Federal do Rio de Janeiro - UFRJ, Sala F210, CT/UFRJ, \\ Cidade Universitária, CP 68505, CEP 21941-972, Rio de Janeiro, RJ, Brasil
}

Received: September 23, 2010; Revised: December 17, 2013

\begin{abstract}
In this work we synthesized pigments capable of developing dental shades when mixed with dental porcelain and fired at appropriate temperatures. TiO2-xCeO2 pigments $(x=2,6,10,13$ and $18 \mathrm{~mol} \%)$ were synthesized by the Pechini method. Characterization by thermal analysis revealed the stability of the material at temperatures up to $1200{ }^{\circ} \mathrm{C}$. X-ray diffraction showed stable crystalline phases (rutile to $\mathrm{TiO} 2$ and cerianite to $\mathrm{CeO} 2$ ) for all pigments studied. Color of pigments was characterized by colorimetric coordinates according to the CIELAB method and reflectance measurements in the visible region. Through colorimetric analysis it was possible to verify the potential use of these pigments in dental ceramics.
\end{abstract}

Keywords: polymeric precursor method, CIElab, ceramic pigments, dental application

\section{Introduction}

Ceramics have been used commercially as synthetic tooth filling materials and in dental prosthesis. In conventional dental ceramics, such as dental porcelain, a ceramic pigment or a combination of several pigments is incorporated into the composition. Pigments' crystals remain sufficiently intact during the firing process to impart the desired color in the finished product ${ }^{1}$.

In order to produce acceptable colors for use in dental ceramics, pigments which produce yellow to yellow-red shades in the crystallized product are needed. There is no single transition metal or rare earth metal ion which yields a clear yellow effect, except those that are restricted, such as uranium. However, methods for combining certain pairs of colorant ions have been described, such as the combination of $\mathrm{Ce}$ and $\mathrm{Ti}$ oxides that can produce yellow colors in glazes and glasses ${ }^{2,3}$.

Property studies on $\mathrm{Ce}$ and $\mathrm{Ti}$ oxide systems are promising for various reasons. They can be applied to surfaces which need yellow pigments, including application in dental ceramics, due to the fact that titaniumbased and rare-earth pigments present low toxicity, high thermal and chemical resistance ${ }^{4}$ and to the fact that they have already been mentioned in biomedicine ${ }^{5}$. Cerium oxide $\left(\mathrm{CeO}_{2}\right)$ is already used in dentistry to simulate the fluorescence of tooth enamel ${ }^{1}$ and titanium dioxide $\left(\mathrm{TiO}_{2}\right)$ to supply opacity ${ }^{6,7}$.

*e-mail: shirleny@uezo.rj.gov.br
Several methods have been used to prepare Ce and $\mathrm{T} i$ oxides, mainly the conventional ceramic method. However, several studies have demonstrated that the polymeric precursor method (Pechini Method) can provide powders with improved qualities. In this method certain metal-ion chelates forming carboxylic acids are used. Those metal chelates are polyestherified when heated in polyhydroxy alcohols, giving rise to a resin in which ions are immobilized and the desired oxides are obtained after heat treatment. This method for forming homogeneous powders provides small particle sizes, high purity, low cost and relatively low processing temperature ${ }^{8,9}$.

Taking into consideration what has been aforementioned, this work presents the results from characterization of $\mathrm{TiO}_{2}-\mathrm{xCeO}_{2}$ yellow pigments obtained through the Pechini method, including an insight to their potential application in dental ceramics coloration.

\section{Experimental Procedure}

\subsection{Synthesis of $\mathrm{TiO}_{2}-x \mathrm{CeO}_{2}$ pigments}

$\mathrm{TiO}_{2}-\mathrm{xCeO}_{2}$ pigments $(\mathrm{x}=2,6,10 \mathrm{~mol} \%)$ were synthesized through the polymeric precursor method ${ }^{9}$. The molar ratio between the citric acid and the metal cation was 3:1, while the citric acid/ethylene-glycol was 1:2.

Alcohol solution (40\%) of titanium (IV) isopropoxide $\left(\mathrm{C}_{12} \mathrm{H}_{28} \mathrm{O}_{4} \mathrm{Ti}, 97 \%\right.$, Aldrich) was slowly added to a 1 molar 
aqueous solution of citric acid $\left(\mathrm{C}_{6} \mathrm{H}_{8} \mathrm{O}_{7}, 99.5 \%\right.$ - Vetec $)$ heated to $70{ }^{\circ} \mathrm{C}$. Next, 0.1 molar aqueous Cerium nitrate hexahydrate solution $\left(\mathrm{Ce}\left(\mathrm{NO}_{3}\right)_{3} \cdot 6 \mathrm{H}_{2} \mathrm{O}, 99 \%\right.$, Sigma) was added varying the amount as desired percentage. Then, ethylene glycol was added $\left(\mathrm{C}_{2} \mathrm{H}_{6} \mathrm{O}_{2}, 99.5 \%\right.$ - Vetec $)$. The temperature was raised to $90{ }^{\circ} \mathrm{C}$, where the system remained for 10 hours. The resins obtained were heat treated at $500{ }^{\circ} \mathrm{C}$ for 4 hours and calcined in air at $1000{ }^{\circ} \mathrm{C}$ for 2 hours. In both heat treatments the heating rate was $10^{\circ} \mathrm{C} / \mathrm{min}$.

\subsection{Preparation of frits and glazes}

For dental ceramics preparation enamel layers composed primarily of frits (feldspar based) and pigments are used. So, Feldspar from the Borborema-Seridó region (northeast of Brazil) was used to prepare the frit. Borax $\left(\mathrm{Na}_{2} \mathrm{~B}_{4} \mathrm{O}_{7} \cdot 10 \mathrm{H}_{2} \mathrm{O}\right.$, 99.5-105\%, Vetec) and carboxymethylcellulose (CMC, Synth) were analytical grades.

Frits were obtained through the melting of borax (20\%) and feldspars $(80 \%)$ at temperatures of the order of $1100{ }^{\circ} \mathrm{C}$ and quenched in water.

For glaze preparation, the proportions 1 and $2 \mathrm{wt} \%$ of pigments to a mass of frit were used (named $\mathrm{RTiO}_{2}-$ $\mathrm{XCeO}_{2} .1 \%$ and $\mathrm{RTiO}_{2}-\mathrm{XCeO}_{2} .2 \%$ in the text). $0.5 \mathrm{~mL}$ of CMC solution at $0.01 \%$ was used as organic binder, the mixture was homogenized and applied with a brush on the alumina substrates (supplied by Saint Gobain, $3.5 \times 3.5 \mathrm{~cm}$ ). The ceramic tiles were dried at $100{ }^{\circ} \mathrm{C}$ for $20 \mathrm{~min}$ and fired at $900{ }^{\circ} \mathrm{C}$ for $30 \mathrm{~min}$.

\subsection{Characterization techniques}

Thermal analyses (TG/DTA) were carried out in a SHIMADZU TA-50WSI (thermogravimetric analysis) and a DTA-50 (differential thermal analysis) at a $10{ }^{\circ} \mathrm{C} / \mathrm{min}$ heating rate up to $1200{ }^{\circ} \mathrm{C}$ in air.

Crystallographic structure of the resultant powders were determined by X-ray diffraction using a Bruker-AXS D5005 diffractometer, Co $\mathrm{K} \alpha$ radiation $(35 \mathrm{kV} / 40 \mathrm{~mA}) ; 2 \theta$ range from $5^{\circ}$ to $80^{\circ}$. The chemical composition was analyzed by $\mathrm{X}$-ray fluorescence, in an S4 Bruker equipment.

$\mathrm{L} * \mathrm{a} * \mathrm{~b} *$ color parameters and diffuse reflectance of fired pigments and ceramic tiles were measured by a Color Touch colorimeter, using D65 illumination in an angle of $2^{\circ}$ and also a Vita Easyhade spectrophotometer.

\section{Results and Discussion}

\subsection{Glaze characterization}

The chemical composition for the feldspar used in the preparation of the frit is provided in Table 1. Its chemical analysis has evidenced that this mineral presents the requested characteristics to be applied as a glaze, given that its impurities content (iron and other colorant oxides) is low ${ }^{5}$. In addition, frits based on feldspar composition are common to obtain ceramic glazes for dental use.

$\mathrm{X}$-ray diffraction has indicated that this feldspar is a mixture of albite (sodic feldspar- $\mathrm{NaAlSi}_{3} \mathrm{O}_{8}$ ) and ortoclase (potassic feldspar - $\mathrm{KAlSi}_{3} \mathrm{O}_{8}$ ), Figure 1a, present almost in the same proportion as it can be verified in Table 1 (concentration of $\mathrm{Na}_{2} \mathrm{O}$ and $\mathrm{K}_{2} \mathrm{O}$ ). In agreement with the phase diagram under these conditions, feldspar presents a

Table 1. Chemical Composition of the feldspar used in the preparation of the frit.

\begin{tabular}{cccc}
\hline Substances & weight $\%$ & Substances & weight \% \\
\hline $\mathrm{SiO}_{2}$ & 66.0 & $\mathrm{~K}_{2} \mathrm{O}$ & 5.5 \\
$\mathrm{Al}_{2} \mathrm{O}_{3}$ & 20.0 & $\mathrm{Rb}_{2} \mathrm{O}$ & 0.07 \\
$\mathrm{CaO}$ & 0.26 & $\mathrm{NiO}$ & 0.11 \\
$\mathrm{Na}_{2} \mathrm{O}$ & 5.9 & Ashes & 1.3 \\
$\mathrm{P}_{2} \mathrm{O}_{5}$ & 0.34 & - & - \\
\hline
\end{tabular}

Table 2. Concentrations of $\mathrm{Ce}$ in $\mathrm{TiO}_{2}-\mathrm{xCeO}_{2}$.

\begin{tabular}{cccc}
\hline \multicolumn{4}{c}{ Concentrations of Ce (mol\%) } \\
\hline $\begin{array}{c}\text { Nominal } \\
\text { (as designed) }\end{array}$ & $\begin{array}{c}\text { Experimental } \\
\text { (as analyzed) }\end{array}$ & $\begin{array}{c}\text { Nominal } \\
\text { (as designed) }\end{array}$ & $\begin{array}{c}\text { Experimental } \\
\text { (as analyzed) }\end{array}$ \\
\hline 0 & 0 & 10.0 & 10.2 \\
2.0 & 2.0 & 14.0 & 13.0 \\
6.0 & 6.2 & 20.0 & 17.0 \\
\hline
\end{tabular}

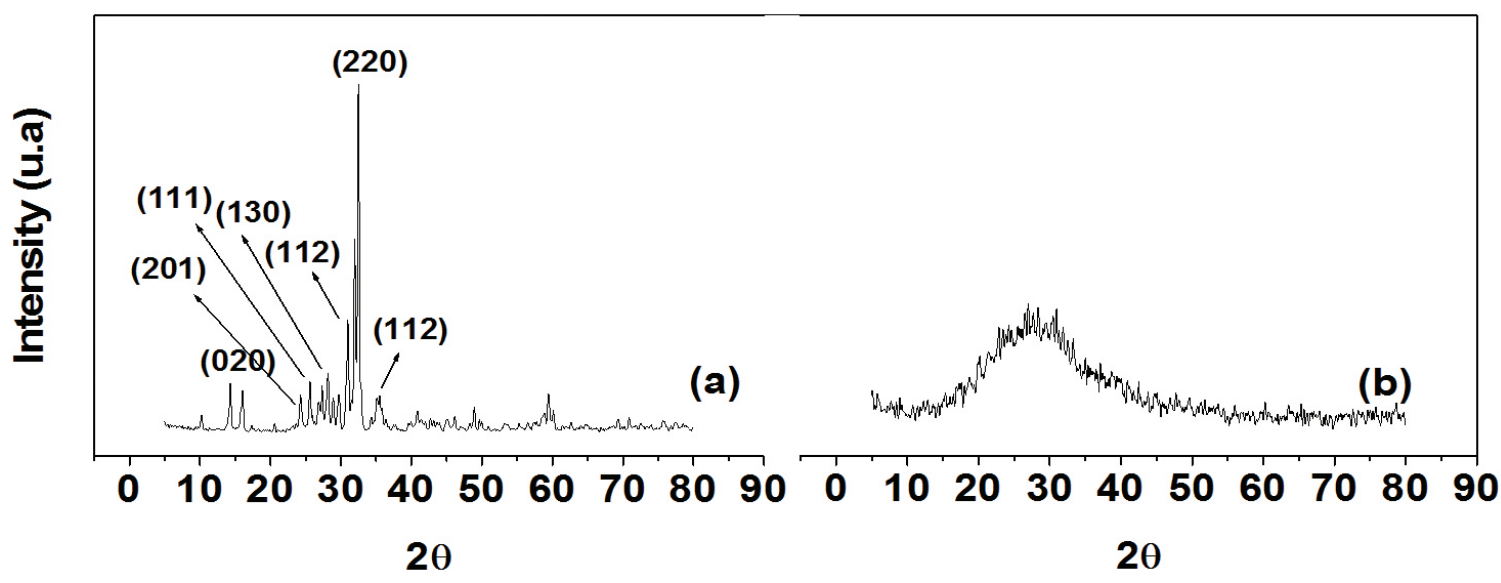

Figure 1. X-ray diffraction patterns for (a) feldspar and (b) frit. 
melting temperature of the order of $1200{ }^{\circ} \mathrm{C}$. However, it was possible to apply an even lower temperature $\left(1100^{\circ} \mathrm{C}\right)$ due to the borax incorporation into the composition ${ }^{10}$.

The X-ray diffraction pattern, Figure 1b, shows that the frit obtained is entirely amorphous, with a halo centered around $2 \theta=27^{\circ}$ characteristic of glassy materials, without any crystalline phases remaining from the original feldspar ${ }^{11}$.

\subsection{Pigments characterization}

\subsubsection{Chemical composition, thermal analysis and crystalline phases}

The compositional homogeneity of the synthesized product achieved with the use of the Pechini method could be confirmed through the results of the chemical analysis of the pigments. The obtained data, summarized in Table 2, give good evidence of the agreement between the theoretical and experimental values.

Figure 2 shows the TG and DTA curves for the polymeric resin precursor of the $\mathrm{TiO}_{2}-0,1 \mathrm{CeO}_{2}$ pigment. In the TG curve profile four mass loss regions are seen: the first, between 30 and $200{ }^{\circ} \mathrm{C}$, with $20.64 \mathrm{wt} \%$ loss, was related to the elimination of water physically adsorbed and the alcohol utilized as a solvent; the second and third regions (50 wt \% loss), from 200 to $380^{\circ} \mathrm{C}$, were attributed to organic matter combustion; and the fourth one, about $11.9 \mathrm{wt} \%$ loss,

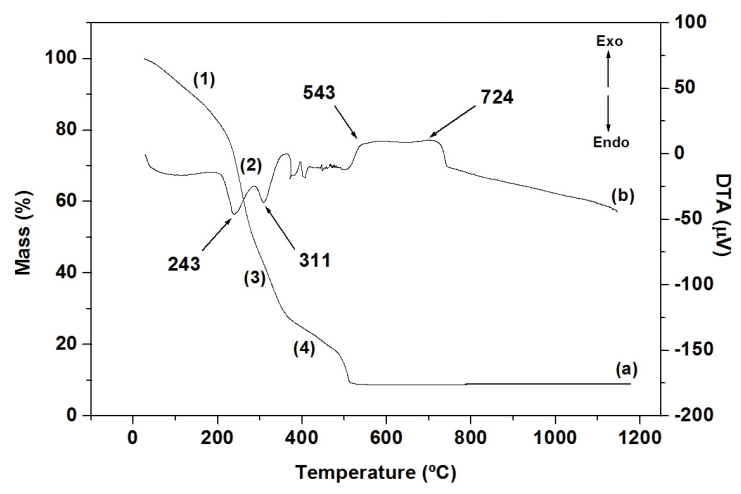

Figure 2. Curves of (a) TG and (b) DTA of the precursor resin of $\mathrm{TiO}_{2}-0.1 \mathrm{CeO}_{2}$. between 380 and $520^{\circ} \mathrm{C}$, was associated with the elimination of chemically combined water and residual organic matter.

The events observed in the analysis of mass loss could be confirmed through the constructional details of the DTA profile, Figure $2 b$, where endothermic peaks were found in the $200-500{ }^{\circ} \mathrm{C}$ region - related to the combustion of organic matter $\left(243\right.$ and $\left.311^{\circ} \mathrm{C}\right)$. The exothermic peaks at 543 and $724{ }^{\circ} \mathrm{C}$ were associated with the formation of $\mathrm{TiO}_{2}$ in amorphous state and to the phase change to rutile, respectively, as confirmed by the $\mathrm{x}$-ray diffraction analysis.

$\mathrm{TiO}_{2}-\mathrm{xCeO}_{2}$ pigments in powder form were studied through XRD for the samples fired at $500{ }^{\circ} \mathrm{C}$ (precursor powder) and further calcined at $1.000^{\circ} \mathrm{C}$ (calcined powder), as shown in Figure 3.

The XRD pattern for pure titanium dioxide showed that the powder fired at $500{ }^{\circ} \mathrm{C}$ is still amorphous, and only after calcination at $1.000{ }^{\circ} \mathrm{C}$ it became entirely crystalline in the rutile phase.

The analysis of XRD patterns for $\mathrm{TiO}_{2}$ samples containing additions of cerium oxide, Figure 4 , as well as the peaks corresponding to the rutile phase, point out two peaks corresponding to the cerianite phase, for samples containing $6 \mathrm{~mol} \%$ or more of cerium oxide, its intensity growing with the increase in the cerium oxide content, disclosing the dual-phase nature of the synthesized product $\left(\mathrm{TiO}_{2}+\mathrm{CeO}_{2}\right)$. This result was expected since some authors had already suggested that cerium oxides were not capable of forming solid solutions with $\mathrm{TiO}_{2}$, as usually only mixture of oxides were obtained ${ }^{12}$.

\subsubsection{Colorimetric characterization}

Colors are usually characterized using the CIElab system, which provides three color parameters, named $\mathrm{L}^{*}$, $\mathrm{a}^{*}$ and $\mathrm{b}^{*}$. Index $\mathrm{L}^{*}$ corresponds to brightness variation, in a scale from 0 (black) to 100 (white); a* represents color variation from green $(-60)$ to red $(+60)$; and $b^{*}$ color variation from blue $(-60)$ to yellow $(+60)^{13}$.

The colorimetric results for $\mathrm{TiO}_{2}-\mathrm{xCeO}_{2}$ pigments are shown in Table 3 , where the negative values of a* indicate predominance of the green color over red while the high values of $b^{*}$ correspond to the yellow color, which is the real aspect of the samples. Through the obtained values, the effect of the cerium oxide was verified in the development of the yellow color, because the introduction of only $2 \mathrm{~mol} \%$ of

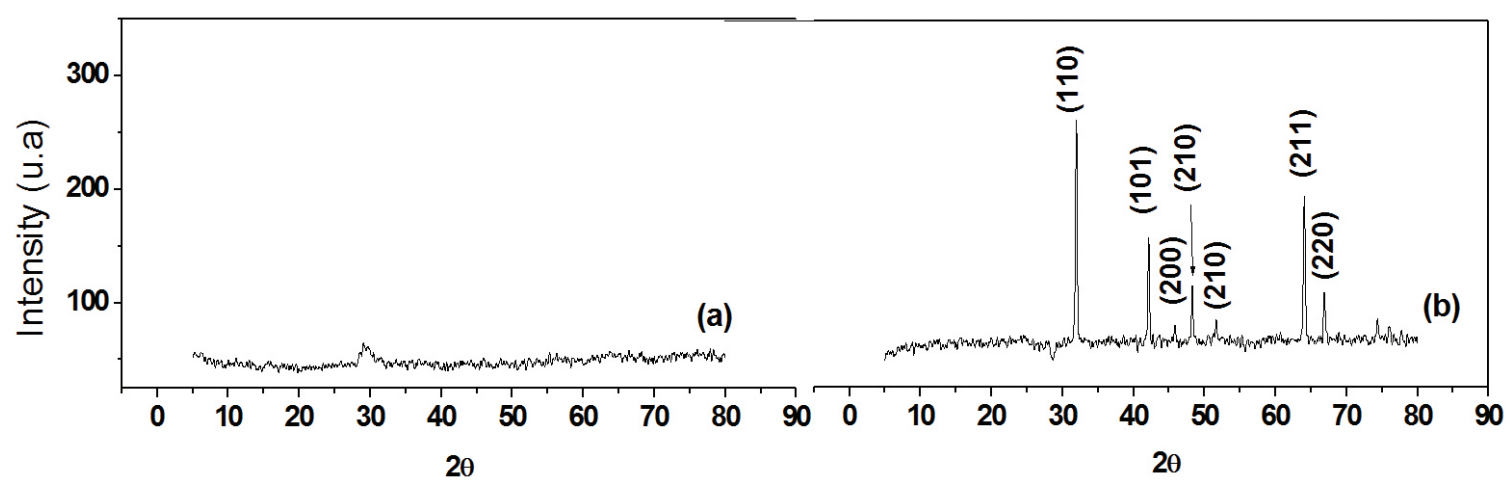

Figure 3. X-ray diffraction patterns for $\mathrm{TiO}_{2}$ calcined: (a) $500{ }^{\circ} \mathrm{C}$ and (b) $1.000{ }^{\circ} \mathrm{C}$. 


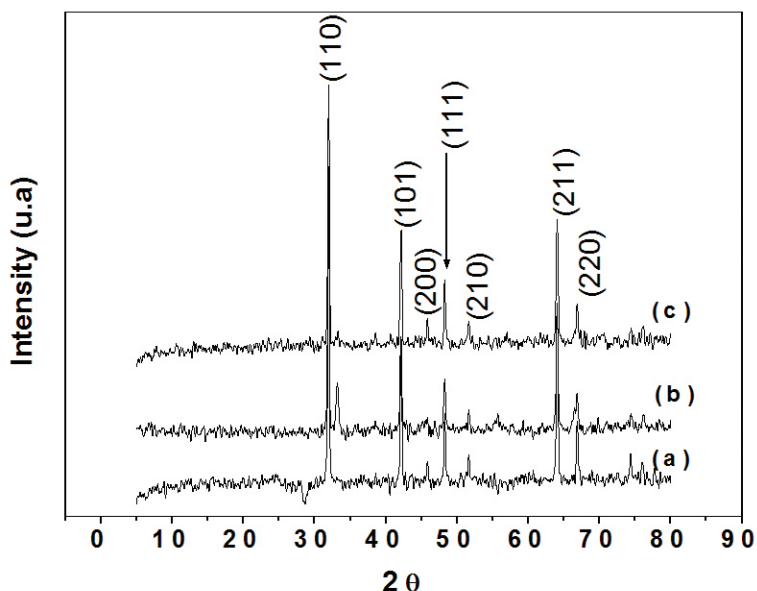

Figure 4. $\mathrm{X}$-ray diffraction patterns (a) $\mathrm{TiO}_{2}$, (b) $\mathrm{TiO}_{2}-0.02 \mathrm{CeO}_{2}$, (c) $\mathrm{TiO}_{2}-0.06 \mathrm{CeO}_{2}$, (d) $\mathrm{TiO}_{2}-0.10 \mathrm{CeO}_{2}$, (e) $\mathrm{TiO}_{2}-0.13 \mathrm{CeO}_{2}$ and (f) $\mathrm{TiO}_{2}-0.17 \mathrm{CeO}_{2}$.

Table 3. Colorimetric parameters of $\mathrm{TiO}_{2}-\mathrm{xCeO}_{2}$ pigments.

\begin{tabular}{lccccccc}
\hline \multicolumn{1}{r}{ Pigments } & $\mathbf{L}$ & $\mathbf{a}^{*}$ & $\mathbf{b}^{*}$ & \multicolumn{1}{c}{ Pigments } & $\mathbf{L}^{*}$ & $\mathbf{a}^{*}$ & $\mathbf{b}^{*}$ \\
\hline $\mathrm{TiO}_{2}$ & 94.04 & -0.71 & 6.80 & $\mathrm{TiO}_{2}-0.10 \mathrm{CeO}$ & 89.59 & -3.68 & 29.47 \\
$\mathrm{TiO}_{2}-0.02 \mathrm{CeO}_{2}$ & 86.51 & -3.06 & 31.48 & $\mathrm{TiO}_{2}-0.13 \mathrm{CeO}_{2}$ & 90.05 & -3.63 & 31.13 \\
$\mathrm{TiO}_{2}-0.06 \mathrm{CeO}_{2}$ & 89.93 & -3.95 & 30.17 & $\mathrm{TiO}_{2}-0.17 \mathrm{CeO}_{2}$ & 87.42 & -3.88 & 33.97 \\
\hline
\end{tabular}

this oxide produced an increase of the value of $b *$ from 6.80 in pure titanium dioxide to 31.48 in the mixture of oxides.

It was also observed that an increase of the cerium oxide concentration did not produce a significant change of color coordinates. This might be due to the fact that the $\mathrm{TiO}_{2}-\mathrm{xCeO}$, pigment containing $6 \mathrm{~mol} \%$ ceria reached its saturation limit.

XRD results did not indicate any sharp evidence of cerium oxide in the titanium dioxide network, i.e., no solid solution was obtained, only the mixture of oxides. However, the reflectance curve, Figure 5, indicated that there was some interaction between these oxides giving rise to the observed yellow color ${ }^{4}$, since the absorption band of pure cerium oxide centered at about $560 \mathrm{~nm}$ moves to approximately $460 \mathrm{~nm}$ in the mixture of oxides, pointing out the occurrence of an interaction that could be of the type charge transfer from titanium cation to the cerium cation.

The yellow color has already been observed in thin films of the cerium-titanium mixed oxide ${ }^{5,10}$. Titanium dioxide clearly represents the whitest color ${ }^{11}$ and $\mathrm{CeO}_{2}$ itself does not produce any color in glass ${ }^{14}$, so the yellow color is clearly the result of a complex interaction between the electronic structures of both oxides, whose interactions are modified with the light wave.

\subsubsection{Potential application of the pigments}

The potential application of the pigments was evaluated by comparing the colorimeters data from ceramic glazes containing these synthesized pigments to those from ceramic glaze used for dental restorations (VITA products). Four commercial references were used, see Table 4.

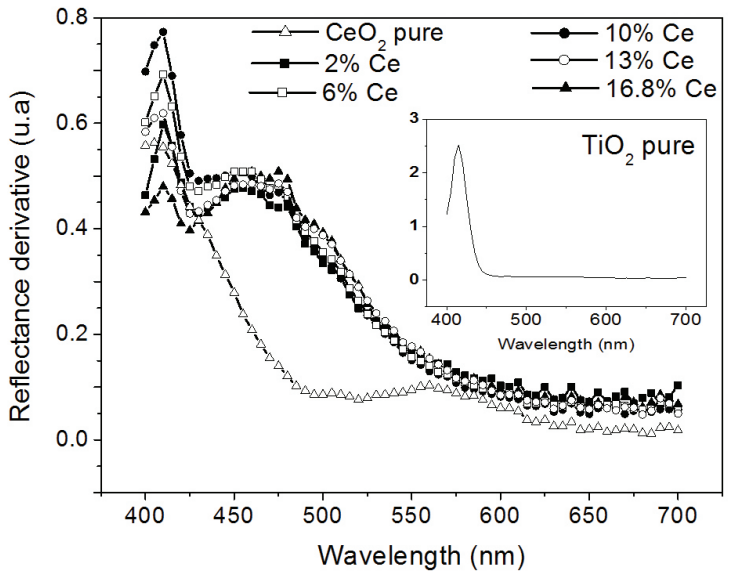

Figure 5. First derivative reflectance curve for $\mathrm{TiO}_{2}-\mathrm{xCeO}_{2}$ pigment. Insert: First derivative reflectance curve for pure $\mathrm{TiO}_{2}$.

Table 5 provides the values for $\mathrm{L}^{*}, \mathrm{a}^{*}$ and $\mathrm{b}^{*}$ of the glazes containing 1 and $2 \mathrm{wt} \%$ of $\mathrm{TiO}_{2}-\mathrm{xCeO}_{2}$ and the values obtained from commercial references. It was verified that samples made up with titanium-cerium pigments provided similar values to those from commercial dentins. Indeed, the values $a^{*}=-0.85$ and $b^{*}=6.72$ for the experimental $\mathrm{RTiO}_{2}-0.06 \mathrm{CeO}_{2} 1 \%$ sample are comparable to the values $a^{*}=-0.84$ and $b^{*}=6.93$ of reference 3 (commercial sample).

The increase in pigment concentration produced only an increase in the value of $b^{*}$, leading the experimental samples to closer values to those provided by reference 1 (commercial sample). 
The CIELab method can also be used for evaluation of the instrumental tolerance $\left(\Delta \mathrm{E}^{*}\right)$ or the range of clinically acceptable color difference between the prosthesis and the natural tooth color of a patient ${ }^{15}$. This analysis is accomplished by applying Equation 1, presented below:

$\Delta \mathrm{E}^{*}=\sqrt{\left(\Delta \mathrm{L}^{*}\right)^{2}+\left(\Delta \mathrm{a}^{*}\right)^{2}+\left(\Delta \mathrm{b}^{*}\right)^{2}}$

Taking into account the criteria of $\Delta \mathrm{E}^{*}>3.6$ as the acceptable level of color difference ${ }^{15,16}$ above mentioned, Table 6 evidences that many of the experimental samples fit the requirements needed for approval as potential coating material in dental prosthesis application.
The Vita Easy-shade dental spectrophotometer, capable of scanning a small area on the surface of a dental restoration material, was used in order to classify the colors of the samples of the present study according to Vita shade scales: Vita 3D-Master (VI) and Vita Classic (CL), as well as to get CIEL*a*b* parameters. Five measures in each square alumina plate were accomplished with this equipment (at each of the four corners and the fifth at the center of the square plate, whose values gave an average value for each sample).

Table 7 presents some of the results obtained through Vita Easy-shade. All of the experimental porcelain glazes

Table 4. Description of the commercial references used.

\begin{tabular}{cccc}
\hline Ref. of dentins & Trademark & Ref. of dentins & Trademark \\
\hline Reference 1 & 2M3 base dentin & Reference 3 & 3M2 dentin \\
Reference 2 & 3M2 dentin Vita & Reference 4 & Base Dentin 3R2.5 \\
\hline
\end{tabular}

Table 5. Colorimetric parameters for frit-pigment glaze and commercial glaze.

\begin{tabular}{|c|c|c|c|c|c|c|c|}
\hline Pigments & $\mathbf{L} *$ & $a^{*}$ & b* & Pigments & $\mathbf{L} *$ & $\mathbf{a}^{*}$ & $\mathbf{b}^{*}$ \\
\hline $\mathrm{RTiO}_{2}-0.02 \mathrm{CeO}_{2} .1 \%$ & 91.12 & -0.94 & 7.36 & $\mathrm{RTiO}_{2}-0.10 \mathrm{CeO}_{2} .2 \%$ & 90.65 & -1.08 & 9.67 \\
\hline $\mathrm{RTiO}_{2}-0.06 \mathrm{CeO}_{2} .1 \%$ & 91.24 & -0.85 & 6.72 & $\mathrm{RTiO}_{2}-0.13 \mathrm{CeO}_{2} .2 \%$ & 90.48 & -0.95 & 8.21 \\
\hline $\mathrm{RTiO}_{2}-0.10 \mathrm{CeO}_{2} .1 \%$ & 90.73 & -0.92 & 8.25 & $\mathrm{RTiO}_{2}-0.17 \mathrm{CeO}_{2} .2 \%$ & 90.06 & -1.15 & 10.33 \\
\hline $\mathrm{RTiO}_{2}-0.13 \mathrm{CeO}_{2} .1 \%$ & 91.19 & -0.83 & 7.05 & Reference 1 & 91.18 & -1.21 & 11.38 \\
\hline $\mathrm{RTiO}_{2}-0.17 \mathrm{CeO}_{2} .1 \%$ & 90.73 & -0.91 & 7.80 & Reference 2 & 92.61 & -0.82 & 6.12 \\
\hline $\mathrm{RTiO}_{2}-0.02 \mathrm{CeO}_{2} .2 \%$ & 89.98 & -1.17 & 11.58 & Reference 3 & 92.38 & -0.84 & 6.93 \\
\hline $\mathrm{RTiO}_{2}-0.06 \mathrm{CeO}_{2} .2 \%$ & 90.33 & -1.13 & 10.01 & Reference 4 & 91.36 & -0.82 & 9.38 \\
\hline
\end{tabular}

Table 6. Color difference $\left(\Delta \mathrm{E}^{*}\right)$ between commercial glaze and experimental glaze.

\begin{tabular}{|c|c|c|c|c|}
\hline Glazes & $\Delta \mathbf{E}^{*} / \operatorname{Ref} 1$ & $\Delta \mathbf{E}^{*} / \operatorname{Ref} 2$ & $\Delta \mathbf{E}^{* /} \operatorname{Ref} 3$ & $\Delta \mathbf{E} * / \operatorname{Ref} 4$ \\
\hline $\mathrm{RTiO}_{2}-0.06 \mathrm{CeO}_{2} .1 \%$ & 4.67 & 1.50 & 1.16 & 2.67 \\
\hline $\mathrm{RTiO}_{2}-0.10 \mathrm{CeO}_{2} .1 \%$ & 3.18 & 2.84 & 2.11 & 1.30 \\
\hline $\mathrm{RTiO}_{2}-0.13 \mathrm{CeO}_{2} .1 \%$ & 4.35 & 1.70 & 1.20 & 2.34 \\
\hline $\mathrm{RTiO}_{2}-0.17 \mathrm{CeO}_{2} .1 \%$ & 3.62 & 2.52 & 1.87 & 1.70 \\
\hline $\mathrm{RTiO}_{2}-0.06 \mathrm{CeO}_{2} .2 \%$ & 1.61 & 4.52 & 3.71 & 1.25 \\
\hline $\mathrm{RTiO}_{2}-0.10 \mathrm{CeO}_{2} .2 \%$ & 1.79 & 4.06 & 3.25 & 0.81 \\
\hline $\mathrm{RTiO}_{2}-0.13 \mathrm{CeO}_{2} .2 \%$ & 3.26 & 2.99 & 2.29 & 1.47 \\
\hline $\mathrm{RTiO}_{2}-0.17 \mathrm{CeO}_{2} .2 \%$ & 1.54 & 4.93 & 4.13 & 1.64 \\
\hline
\end{tabular}

Table 7. Dental shade classification and CIEL*a*b* parameters for commercial glazes and experimental glazes.

\begin{tabular}{|c|c|c|c|c|c|c|c|c|}
\hline \multirow[t]{2}{*}{ Glazes } & \multirow[t]{2}{*}{$\mathbf{C L} *$} & \multirow[t]{2}{*}{$\mathbf{V I} * *$} & \multicolumn{3}{|c|}{ Color Touch colorimeter } & \multicolumn{3}{|c|}{ Vita Easy Shade spectrophotometer } \\
\hline & & & $\mathbf{L}^{*}$ & $\mathbf{a}^{*}$ & $\mathbf{b}^{*}$ & $\mathbf{L}^{*}$ & $\mathbf{a}^{*}$ & $\mathbf{b}^{*}$ \\
\hline $\mathrm{RTiO}_{2}-0.02 \mathrm{CeO}_{2} 1 \%$ & A1 & $1 \mathrm{~m} 2$ & 91.12 & -0.94 & 7.36 & 88.68 & -0.34 & 18.30 \\
\hline $\mathrm{RTiO}_{2}-0.06 \mathrm{CeO}_{2} 1 \%$ & A1 & $1.5 \mathrm{~m} 1.5$ & 91.24 & -0.85 & 6.72 & 86.48 & -0.50 & 17.80 \\
\hline $\mathrm{RTiO}_{2}-0.10 \mathrm{CeO}_{2} 1 \%$ & A1 & $1.5 \mathrm{~m} 1$ & 90.73 & -0.92 & 8.25 & 86.52 & -2.48 & 14.62 \\
\hline $\mathrm{RTiO}_{2}-0.13 \mathrm{CeO}_{2} 1 \%$ & A1 & $1 \mathrm{~m} 1.5$ & 91.19 & -0.83 & 7.05 & 88.30 & -0.34 & 17.60 \\
\hline $\mathrm{RTiO}_{2}-0.17 \mathrm{CeO}_{2} 1 \%$ & A1 & $1 \mathrm{~m} 1.5$ & 90.73 & -0.91 & 7.80 & 87.24 & -0.22 & 16.18 \\
\hline Reference 1 & $\mathrm{~A} 2$ & $2 \mathrm{~m} 3$ & 91.18 & -1.21 & 11.38 & 81.58 & 0.40 & 22.70 \\
\hline Reference 2 & A1 & $1 \mathrm{~m} 1.5$ & 92.61 & -0.82 & 6.12 & 90.26 & -0.30 & 14.94 \\
\hline Reference 3 & A1 & $1.5 \mathrm{~m} 1$ & 92.38 & -0.84 & 6.93 & 88.56 & -0.16 & 15.40 \\
\hline Reference 4 & A1 & $1 \mathrm{~m} 1.5$ & 91.36 & -0.82 & 9.38 & 88.60 & 0.38 & 20.60 \\
\hline
\end{tabular}

*Vita Classic, **Vita 3D-Master. 
studied could match one range of dental colors, their CIEL*a*b* parameters fit those previously determined by the Color Touch colorimeter. Moreover, some samples could be classified in the range of shades belonging to other commercial references.

An additional comment is necessary: for each sample analysed, the CIEL*a*b* parameters obtained through the Vita Easy Shade spectrophotometer were slightly different from those obtained through the Color Touch colorimeter. This difference can be easily explained given that the Color Touch colorimeter requires the use of large scanning areas (at least $3 \mathrm{~cm} \times 3 \mathrm{~cm}$ ), giving an average result, without discriminating eventual short-range deviation in color. On the other hand, the Easy Shade spectrophotometer scans very small areas (e.g., $4 \mathrm{~mm} \times 4 \mathrm{~mm}$ ) and, therefore, it reads in a much more discriminating way. Also color shades present sensitivity in relation to processing techniques and conditions and techniques for measuring color shades (as scanning angle, pressure, light intensity and wave-length). Dental laboratories use methods somewhat different from those used in this work. Even under these natural difficulties, the present work has evidenced that $\mathrm{TiO}_{2}-\mathrm{xCeO}_{2}$ pigments have potential application in the coloration of porcelain dentins.

\section{References}

1. Santos SF, De Andrade MC, Sampaio JA, Da Luz AB and Ogasawara T. Synthesis of ceria-praseodymia pigments by citrate-gel method for dental restorations. Dyes and Pigments. 2007; 75:574-579. http://dx.doi.org/10.1016/j. dyepig.2006.07.005

2. Silvestria S, Kubaskib ET, Ribeiroa RAP, De Lazaroa SR, Pianaroa SA and Tebcherania SM. Optical and morphological properties of $\mathrm{Ce}$-doped $\mathrm{TiO}_{2}-\mathrm{MoO}_{3}$ ceramic matrix. Ceramics International. 2012; 38:847-850. http://dx.doi.org/10.1016/j. ceramint.2011.05.161

3. Martins TS and Isolani PC. Terras raras: aplicações industriais e biológicas Química Nova. 2005; 28:111-117. http://dx.doi. org/10.1590/S0100-40422005000100020

4. Candeia RA, Bernandi MIB, Longo E, Santos IMG and Souza AG. Synthesis and characterization of spinel pigment $\mathrm{CaFe}_{2} \mathrm{O}_{4}$ obtained by the polymeric precursor method. Materials Letters. 2004; 58:569-572. http://dx.doi.org/10.1016/S0167577X(03)00563-9

5. Sanches E. Matérias-Primas para Fabricação de Fritas e Esmaltes Cerâmicos. Cerâmica Industrial. 1997; 2:32-40.

6. Yu B, Ahn J, Lim J and Lee Y. Influence of $\mathrm{TiO}_{2}$ nanoparticles on the optical properties of resin composites. Dental Materials. 2009; 25:1142-1147. http://dx.doi.org/10.1016/j. dental.2009.03.012

7. Sun J, Forster AM, Johnson PM, Eidelman N, Quinn G, Schumacher $\mathrm{G}$ et al. Improving performance of dental resins by adding titanium dioxide nanoparticles. Dental Materials. 2011; 27:972-982. http://dx.doi.org/10.1016/j. dental.2011.06.003

8. Santos SF, De Andrade MC, Sampaio JA, Da Luz AB and Ogasawara $\mathrm{T}$. Thermal study of $\mathrm{TiO}_{2}-\mathrm{CeO}_{2}$ yellow ceramic pigment obtained by the Pechini method. Journal of Thermal

\section{Conclusions}

Pigments of titanium and cerium oxides, with good crystallinity and thermal stability, were synthesized by using the Pechini method with citrate precursor.

The yellow color of the mixed $\mathrm{TiO}_{2}-\mathrm{CeO}_{2}$ pigments generated in this study were classified in the CIEL*a*b* scale through the Color Touch colorimeter and the Vita Easy Shade spectrophotometer that enabled the classification of the colors in two Vita Color Scales.

It was possible to demonstrate the potential application of the studied pigments through the preparation of coating on alumina substrates, whose color results matched the adequate $\Delta \mathrm{E}^{*}$ value for clinically acceptable dental prosthesis materials.

\section{Acknowledgements}

The authors are very grateful to CNPq and FAPERJ for the financial support through PRONEX, to CETEM and PEMM/COPPE/UFRJ for the laboratorial facilities and to Saint Gobain for providing sintered alumina plate substrates.

Analysis and Calorimetry. 2007; 87:743-746. http://dx.doi. org/10.1007/s10973-006-7754-4

9. Mesikova Z, Sulvoca P and Trojan M. Yellow pigments based on $\mathrm{Fe}_{2} \mathrm{TiO}_{5}$ and $\mathrm{TiO}_{2}$. Journal of Thermal Analysis and Calorimetry. 2006; 83:561-563. http://dx.doi.org/10.1007/ s10973-005-7393-1

10. Schairer JF. The Alkali-Feldspar Join in the System. Journal of Gelogy. 1950; 58:515-517. http://dx.doi.org/10.1086/625759

11. Earl DA and Clark DE. Efeitos da Composição da Frita sobre o Desenvolvimento de Cor em Esmaltes de Monoporosa com Zircônio-Vanádio. Cerâmica Industrial. 2001; 6:43-49.

12. Alves VA, Silva LA and Boodts JFC. Análise por difração de raios $\mathrm{X}$ de filmes de óxidos cerâmicos compostos por $\mathrm{IrO}_{2} /$ TiO,/CeO . Química Nova. 2000; 23:608-613. http://dx.doi. org/10.1590/S0100-40422000000500007

13. Quinelato AL, Longo E, Leite ER, Bernardo MIB and Varela JA. Synthesis and sintering of $\mathrm{ZrO}_{2}-\mathrm{CeO}_{2}$ powder by use of polymeric precursor based on Pechini process. Journal of Materials Science. 2001; 26:3825-3830. http://dx.doi. org/10.1023/A:1017950506356

14. Weyl WA and Marboe EC. Formation of amorphous solids and characterization of their structures by energy profiles. Journal of the Society of Glass Technology. 1959; 43:417.

15. Stavridakis MM, Papzoglou E, Seghi RS, Johnston WM and Brantley WA. Effect of different high-palladium metal-ceramic alloys on the color of opaque and dentin porcelain. Journal of Prosthetic Dentistry. 2004; 92:170-178. http://dx.doi. org/10.1016/j.prosdent.2004.05.001

16. Wee AG, Monaghan P and Johnston WM. Variation in color between intended matched shade and fabricated shade of dental porcelain. Journal of Prosthetic Dentistry. 2002; 87:657-666. http://dx.doi.org/10.1067/mpr.2002.125727 